\title{
Profile of Obesity and Comorbidities and their Correlation among Hemodialysis Patients, Elbasan
}

\author{
Brunilda Elezi ${ }^{1}$, Skender Topi ${ }^{2}$, Erjona Abazaj ${ }^{3}$ D \\ ${ }^{1}$ University "Aleksander Xhuvani", Faculty of Technical Medical Science, Elbasan, Albania; ${ }^{2}$ Rectors of "Aleksander Xhuvani" \\ University of Elbasan, Albania, Chief of Surgery Department, Professor of Faculty of Technical Medical Sciences, "Aleksander \\ Xhuvani" University, Elbasan, Albania; ${ }^{3}$ Institute of Public Health, Tirana, Albania
}

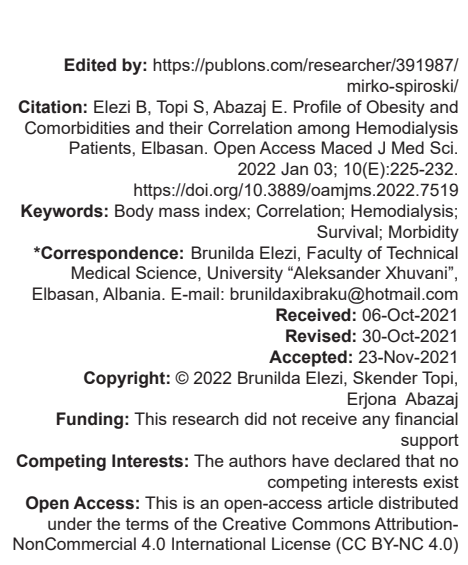

\section{Introduction}

Nowadays, obesity is a major public health problem for both undeveloped and developing countries. Many obese individuals present the metabolic syndrome, which itself consists on resistance toward the absorption of stimulated glucose, glucose intolerance, hyperinsulinemia, hypertriglyceridemia, the low level of high-density lipoprotein cholesterol, and hypertension [1]. The concern about obesity, especially in patients who undergo to the process of hemodialysis remains controversial and confusing [2]. Being overweight, particularly obesity in internal organs contributes to increased risk of metabolic and cardiovascular complications in patients with chronic kidney disease [3]. According to Calle et al., a high body-mass index is directly related with the increased risk of cardiovascular which is associated with higher mortality in the general population [4]. Several epidemiologic studies have shown the effect of obesity in some populations in particular to the people where chronic diseases are more frequent [5], [6], [7], [8]. Geriatric population and patients with cardiovascular system problems present the most concern regarding the obesity [9], [10].

A considerable number of patients undergoing dialysis are obese or much more than obese [11], [12]. However, in some epidemiologic studies, dialysis patients have demonstrated a paradoxically inverse association between obesity and mortality [5], [13], [14], [15], [16], [17]. This making the relationship between weight and outcome among these patients to be complexed [18], [19]. Overweight in this group of patients is usually associated with improved survival [20]. However, differences in mortality between 
different age groups of body mass index (BMI)-based dialysis patients have not been well studied [5].

In our country, there is no complete data on the correlation that exists between obesity and concomitant diseases in people who undergo the dialysis process. Hence, we do not know how BMl affects patients with Diabetes or those with cardiovascular disease (CVD) among dialysis patients. The aim of this study was to assess the prevalence of obesity, correlations with demographic data, biochemical parameters, morbidity as well as predictive BMI capabilities in patients with diabetes and CVD over a 3-year period in chronic hemodialysis patients.

\section{Methodology}

This is a cross-sectional study performed at Elbasan Dialysis Center, where we analyzed a clustering samples with about 160 patients who have undergone the dialysis process during the periods 2016-2018. Before to apply this study, we have communicated with the Head of Hemodialysis Center in Elbasan and after we explained to medical staff the purpose of the study and the path we would choose for data collection we have required permission. After obtaining the permit we started with collection of data. Purposive sampling was performed, and data of the patients participating in this study were obtained from record files of dialysis center, and also, we adopted a standardized questionnaire to obtain other data from patients. Inclusion criteria of this study were: patients receiving HD in Elbasan Dialysis Center; patients who were more than 18 years or older at the time of HD initiation; and patients who had been undergoing long HD, 2-3 times a week for more than 1 years. Demographic and epidemiological information was collected regarding age, sex, occupation status, diabetes, BMI, dialysis modality, and dialysis doses. Data were also obtained on the $1^{\text {st }}$ day of the dialysis treatment process, ethnicity, marital status, living conditions, medical history, history of concomitant diseases (atherosclerotic heart disease, including ischemic heart disease, myocardial infarction, and cardiac arrest, other cardiac diseases, including pericarditis and cardiac arrhythmia, hypertension, cerebrovascular disease, peripheral vascular disease, chronic obstructive pulmonary disease, alcohol, smoking, and cancer).

The subjects have divided a priory into four categories based on the BMI (underweight <19, normal $19-25$, pre-obese $25-30$ and obese $\geq 30 \mathrm{~kg} / \mathrm{m}^{2}$ ). Software SPSS version 20.0 is used to analyse and evaluate the data. The epidemiology data are Epidemiological data are presented in frequency, mean, standard deviation and percentage. Survival analyses using the KaplanMeier test were performed to determine the relationships between BMI with all triggers, mainly with CVD and diabetes Mellitus Type 2 (DMT2). A multi logistic regression analysis for $\mathrm{BMI}$ and biochemistry parameters obtained from patients during the study period and $p$ values $<0.05$ were considered statistically significant.

\section{Results}

The mean age in this study was $52.7 \pm 15.6$ years Of the patients included in this study, $73.1 \%$ (117 cases) were male, and $26.9 \%$ (43 cases) were female. In this study, the most common age groups were $50-59$ years and 60-69 years with $29.4 \%$ (47 cases) and $34.3 \%$ (55 cases), respectively (Table 1 ).

Table 1: Distribution of patients by age-groups

\begin{tabular}{llll}
\hline Variables & Frequency & $\%$ & p value \\
\hline Gender & & & 0.002 \\
Female & 43 & $26.9 \%$ & \\
Male & 117 & $73.1 \%$ & 0.001 \\
Age group & & & \\
18-39 age & 15 & $9.4 \%$ & \\
$40-49$ age & 15 & $9.4 \%$ & \\
$50-59$ age & 47 & $29.4 \%$ & \\
$60-69$ age & 55 & $34.3 \%$ & \\
$\geq 70$ age & 28 & $17.5 \%$ & \\
\hline
\end{tabular}

The average in this study was $52.7 \pm 15.6$ years. Age groups are 50-59 years and 60-69 years with $29.4 \%$ (47 cases) and $34.3 \%$ (55 cases), respectively, A significant relationship was observed between overweight and age Chi-square 1.94 (0.58-2.15) $p=0.001$. As stated earlier, we applied a BMI split to the patients in this study, where four categories of BMI were defined. The categories are: Underweight $<19 \mathrm{~kg} / \mathrm{m}^{2}$, normal weight $19-25 \mathrm{~kg} / \mathrm{m}^{2}$, pre-obese $25-30 \mathrm{~kg} / \mathrm{m}^{2}$ and obese $\geq 30 \mathrm{~kg} / \mathrm{m}^{2}$. In the following table, we present demographic data of the analyzed cases based on their BMI (Table 2).

In the Table 3, we present comorbidity diseases such as diabetes mellitus type 2 and CVDs amidst patients undergoing dialysis for the period 2016-2018.

The highest number of cases is observed for CVD compared to diabetes. In the Figure 1, it is shown the survival of patients with BMI in diabetic and CVD cases.

Kaplan Meir survival was used to analyze survival in relation to BMI parameters for cases of patients with type 2 diabetes mellitus (Figure 1) and cases with CVD (Figure 2). BMI has viewed as an important factor in mortality in both the general population and the population that performs dialysis or those suffering from CVD.

The following Figure 3 shows the incidence of deaths by BMI for all 160 patients for this study at the Elbasan Dialysis Center.

Mortality of dialysis patients during our study period $2016-2018$ was $23.1 \%$ (37/160 cases). The highest number of cases was observed for the BMI category - normal weight $45.9 \%$ (17/37 cases) and for 
Table 2: Baseline characteristics of study according to demographic data and different BMI

\begin{tabular}{|c|c|c|c|c|c|}
\hline Characteristic & Underv weight & Normal weight & Overweight & Obese & Chi-square $95 \% P$ value \\
\hline Age, mean (Std), y & & & & & $1.94(0.58-2.15) 0.001$ \\
\hline $18-39$ & 2 & 6 & 6 & 1 & \\
\hline $40-49$ & 3 & 10 & 1 & 1 & \\
\hline $50-59$ & 2 & 28 & 14 & 3 & \\
\hline $60-69$ & 6 & 24 & 18 & 7 & \\
\hline$\geq 70$ & 1 & 13 & 12 & 2 & \\
\hline Gender & & & & & $2.43(1.07-3.19) 0.002$ \\
\hline Female & 3 & 22 & 12 & 6 & \\
\hline Male & 13 & 59 & 39 & 6 & \\
\hline Residence area & & & & & $3.17(0.12-5.08) 0.005$ \\
\hline Urban area & 8 & 40 & 29 & 7 & \\
\hline Living condition & & & & & $1.67(0.56-3.04)>0.5$ \\
\hline Living with family & 15 & 72 & 46 & 12 & \\
\hline Living alone & 9 & 5 & 9 & 5 & \\
\hline School level & & & & & $3.86(1.07-4.45) 0.023$ \\
\hline Without education & 2 & 6 & 7 & 0 & \\
\hline Primary education & 9 & 28 & 18 & 3 & \\
\hline Secondary & 1 & 43 & 21 & 8 & \\
\hline University & 4 & 4 & 4 & 1 & \\
\hline \multicolumn{6}{|l|}{ Marital statue } \\
\hline Divorced & 0 & 6 & 0 & 1 & \\
\hline Married & 14 & 60 & 45 & 7 & \\
\hline Occupation & & & & & $0.48(0.01-1.99)>0.5$ \\
\hline Unemployed & 9 & 47 & 34 & 5 & \\
\hline Employed & 0 & 5 & 3 & 1 & \\
\hline Invalid & 7 & 29 & 14 & 6 & \\
\hline Monthly income ${ }^{1 *}$ lek & & & & & $0.82(0.03-2.61)>0.5$ \\
\hline Low income $(<200.000)$ & 9 & 53 & 26 & 8 & \\
\hline Moderate (200.000-400.000) & 7 & 25 & 18 & 4 & \\
\hline High income $(>400.000)$ & 0 & 3 & 7 & 0 & \\
\hline Smoking & & & & & 2. $46(0.95-4.19) 0.001$ \\
\hline Yes & 5 & 15 & 6 & 1 & \\
\hline No & 11 & 66 & 45 & 11 & \\
\hline Alcohol use $^{2 *}$ & & & & & $4.07(2.18-7.75) 0.004$ \\
\hline Yes & 6 & 45 & 26 & 2 & \\
\hline No & 10 & 29 & 25 & 9 & \\
\hline
\end{tabular}

*lek=the currency money in Albania

and creatinemia are obtained both before and after the dialysis process. We have calculated their average for each of the indexes.

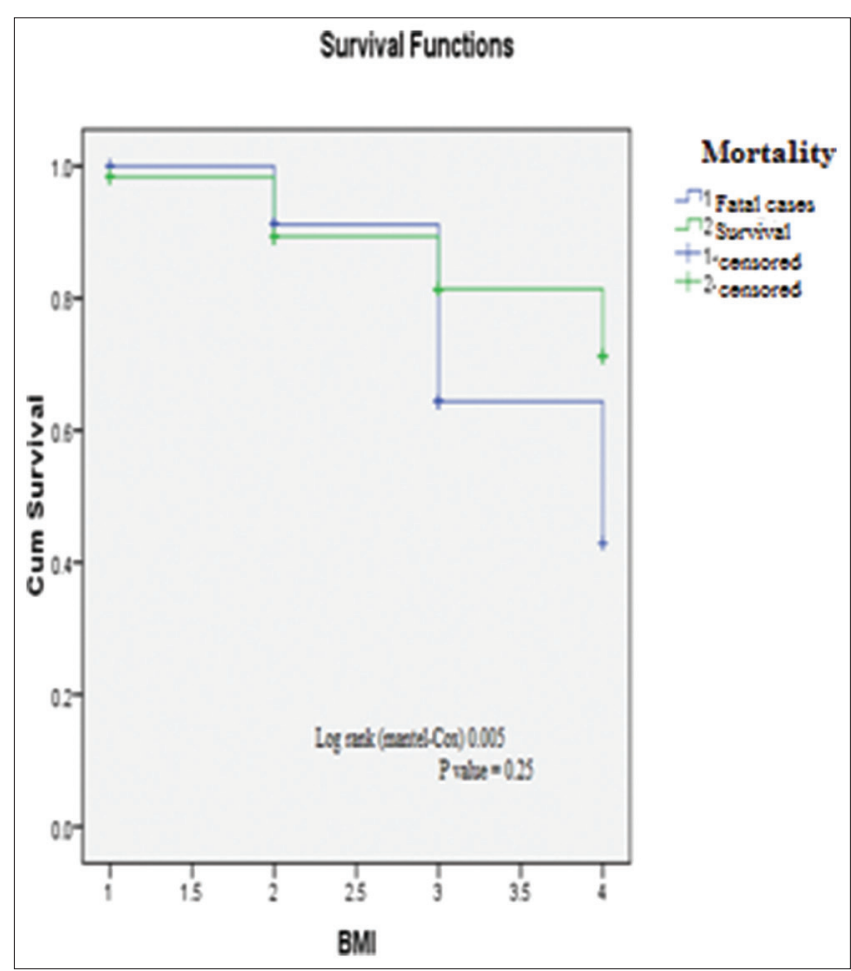

Figure 1. Survival curve of patients with diabetes and BMI at baseline 


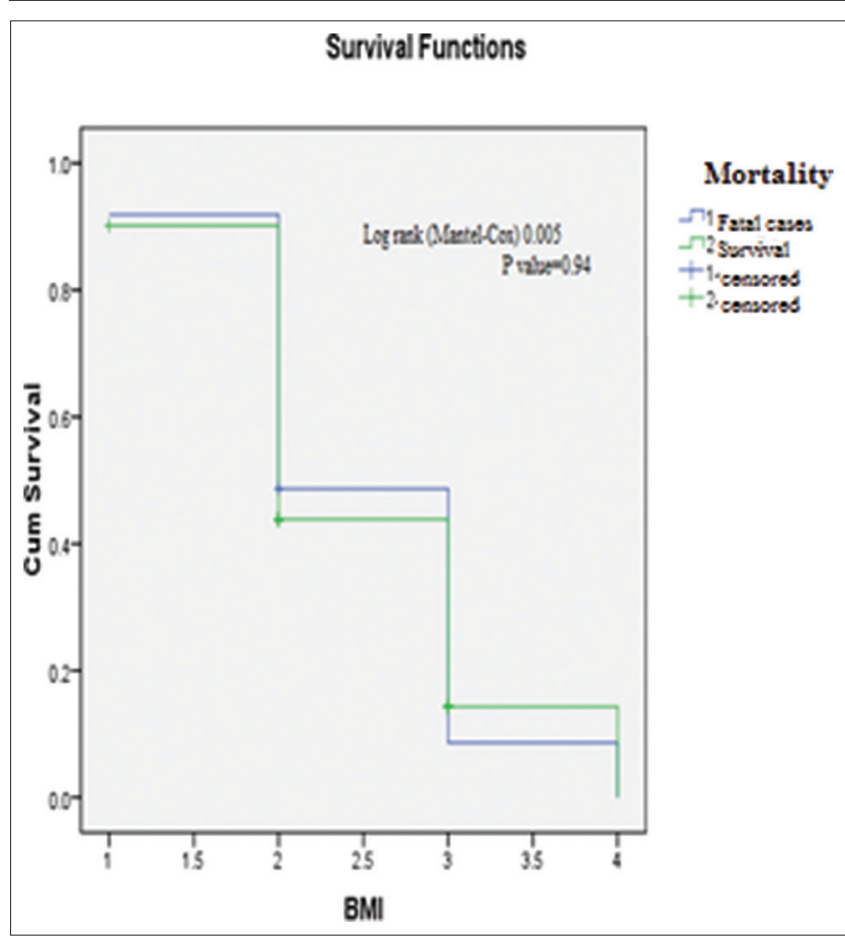

Figure 2. Survival curve of patients with cardiovascular diseases and $\mathrm{BMI}$ at baseline

\section{Discussions}

In the United States of America, according to Flegal et al., obesity has reached epidemic proportions

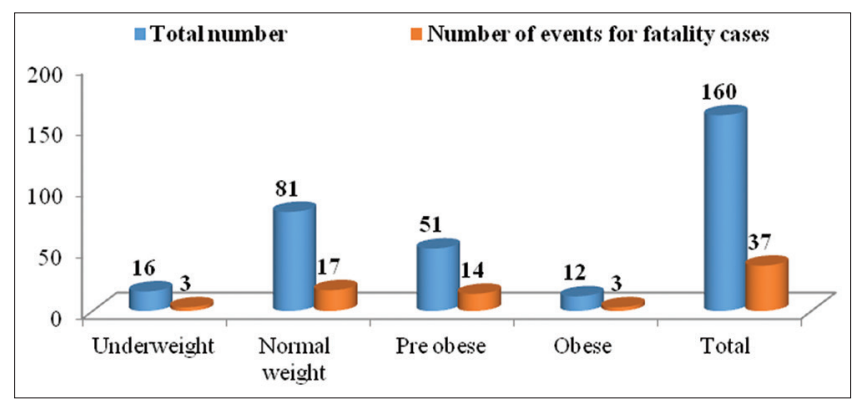

Figure 3. Graphical display of mortality rates by BMI and continues to be a growing problem worldwide [21]. More than 2.5 billion adult people worldwide have a high BMI (BMI> $25 \mathrm{~kg} / \mathrm{m}^{2}$ ) according to the 2017 World Health Organization report [22]. Overweight individuals were estimated to be approximately 1.9 billion and 650 million obese [22], [23]. The epidemic of overweight and obese individuals is being associated with an increasing number of patients with end-stage renal disease (ESRD). This number is expected to double over the next decade [24], [25], driven by the aging of the population and increased prevalence of diabetes mellitus [26] and hypertension [27]. This will occur mainly in developing countries where poverty is many times more evident [28], [29]. Considering the great impact that obesity has on individuals on dialysis as well as other concomitant diseases, this study was undertaken to examine the correlation between obesity and morbidity in hemodialysis patients, Elbasan. This study analyzed the data of 160 patients who underwent a hemodialysis process in Elbasan for 2 years. Table 1 shows the demographic data of 160 cases obtained in this study based on the breakdown of the BMI by the patient. The mean age in this study was $52.7 \pm 15.6$ years. In terms of gender and BMI values, according to Park et al., there is a different body structure between women and men, which affects the effect of BMI on mortality [1].

Men and women also have different proportions of skeletal muscle mass and fat (body composition) that may affect BMI and serum creatinine levels in patients with Hemodialysis (HD) [2], [30]. According to Freitas et al., fat mass change in females is a result of hormonal and reproductive factors [11]. Various studies have reported a higher prevalence of $\mathrm{BMI}$ in females than in males. According to these studies, in the general population, overweight in female's ranges from $42 \%$ to $60 \%$ [11]; whereas in males, it ranges from $27.5 \%$ to $40 \%$ [31], [32]. The same was reported by Postorino et al. in a study conducted in 2009 , in a population of dialysis patients where obese women made up $60 \%$ of the study population while obese men $24 \%$ [33]. Increased BMI is

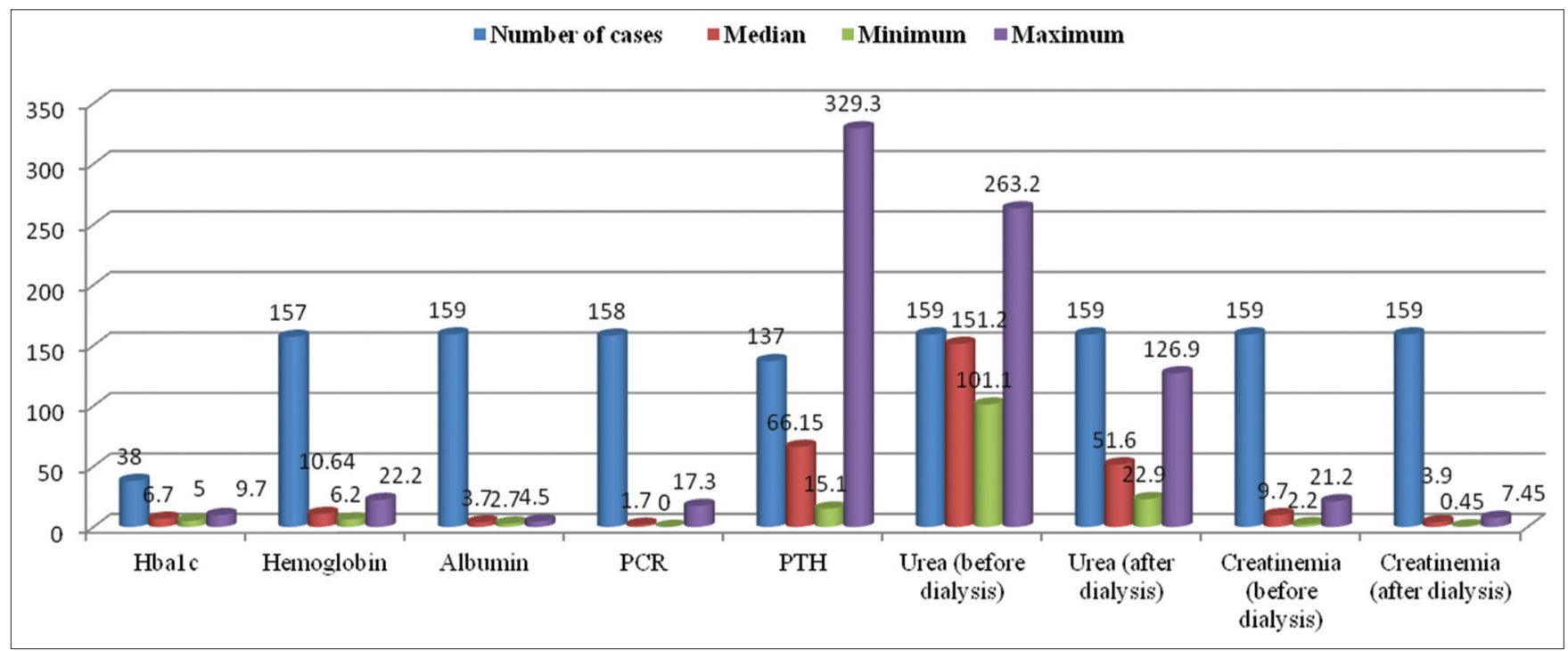

Figure 4. Characteristics of biochemical parameters of dialysis patients 
a factor closely linked to cardiovascular mortality [33], a major cause of death in patients with hemodialysis [34], [35]. However, data on gender and survival in HD patients by BMI are scarce. In this study, $73.1 \%$ (117 cases) were male, and $26.9 \%$ (43 cases) were female. Thus, the relationship between males and females in our study was different from the studies mentioned above. This is because in this center we had a higher number of males than females. For this reason, the prevalence of BMI was consequently higher in men. There is a strong significant relationship between BMI and gender Chisquare 2.43 (1.07-3.19) $p=0.002$. Other studies have highlighted the effect of age on increasing BMI. This increase is most noticeable after the fourth decade of life [11], [32], [36]. According to a study conducted by Ohkawa et al., adults lose about $6-7 \%$ of body mass within 20 years [36]. This spontaneous decrease in body mass is associated with an increase in body fat, and in particular redistribution of fat from the limbs to the abdominal area, thereby producing central obesity. The main factors that may affect these changes are genetic predisposition, eating habits, and decreased physical activity due to increasing age [36], [37], [38]. In this study, the most common age groups were $50-59$ years and 60-69 years with $29.4 \%$ (47 cases) and $34.3 \%$ (55 cases), respectively. Similar results were observed, in this study, in which males and females aged 40 years and over present higher values of obesity. Furthermore, in this study, a significant relationship was observed between overweight and Chi-square age $1.94(0.58-2.15) \mathrm{p}=$ $0.001 .52 .5 \%$ of patients live in urban areas and $47.5 \%$ in rural areas. The majority of patients had 8-year and secondary education with $36.2 \%$, and $45.62 \%$, respectively. $78.75 \%$ of patients were married, $59.4 \%$ were unemployed, and $60 \%$ were living on a very low income. Significant correlations were also observed for urban/rural residence, educational attainment, smoking, and alcohol consumption with BMI. No significant association with BMI was observed for other demographic data. Ekart and Hoys define obesity as a chronic disease that is widespread in the world and serves as a risk factor for type 2 diabetes and hypertension, which in turn are the leading causes of end-stage renal disease [39]. BMI is associated with metabolic disorders which can act as a risk factor for microvascular complications. Obese patients are therefore more likely to develop diabetic renal microvascular complications compared to patients with normal BMI [40], [41]. Some studies have reported that overweight and obesity may be protective for some ESRD patients, without seeing a direct link between BMI and Chronic Kidney Disease (CKD) in diabetic patients. As we have mentioned in the introduction to this article, there is a paradox regarding the effect of BMI on the general population and the population undergoing dialysis [2], [3], [4], [5], [6], [7]. According to many studies, obese individuals in the general population are highly prone to suffering from CVD, leading to increased mortality rates due to obesity [3], [4], [42]. The opposite occurs in populations undergoing dialysis, where a decrease in nutritional measures (such as a low BMI, a decrease in serum cholesterol, or creatinine concentration) is strongly associated with increased morbidity and mortality in dialysis patients [43], [44]. These paradoxical data are referred to as "reverse epidemiology" [45], [46] or as "risk factor paradox" [47], [48], [49]. According to Kamyar et al., understanding these terminologies does not necessarily imply that the principles of vascular pathophysiology are different in individuals with ESRD but may indicate that there are some other overlapping or more dominant factors that cause a significant reversal of the relationship between risk factors, and the result. According to Kamel et al., obesity at different stages of life is an independent predictor of major renal events in patients with type 2 diabetes [50]. For this reason, we require a good understanding of the reverse epidemiological causes in individuals with dialysis, which may help us to improve poor outcomes in this population [42]. In our study, the number of cases of type 2 diabetes mellitus and CVD was more observed for the category of normal body weight index and pre-obesity. Kaplan Meir survival was used to analyze survival to BMI parameters for cases of patients with type 2 diabetes mellitus (Figure 1) and cases with CVD (Figure 2). Although various studies have reported a significant association for survival between cardiovascular or diabetic diseases based on BMI [42], [43], [44], [45], [46], [47], [48], [49], in this study, we did not observe a statistically significant difference in survival and DMT2 and CVD. For both cases, the p-value was $>0.05$. The mortality of dialysis patients during our study period 2016-2018 was 23.1\% (37/160 cases). The highest number of cases was observed for the BMI category - normal weight of $45.9 \%$ (17/37 cases), and the pre-obesity category $37.8 \%$ (14/37 cases). Based on the statistical processing, no correlation was found regarding BMI, and mortality/survival of the cases analyzed in this paper (Pearson Correlation -0.065, $p=0.413$ ). Based on multi logistic regression analysis for BMI and biochemistry parameters obtained from patients during the study period, we can say that a strong significant correlation was found for Chi-square 5.08 hemoglobin index, $p=0.024$; for urea index after Chi-square dialysis 60.2, $p=0.001$ and creatinemia index after Chi-square dialysis $2.77, p$ $=0.042$. For other biochemical indices, no significant association was observed. In the statistical analysis of some of the mortality factors in the population performing the dialysis process, a strong significant association with mortality was observed for 50-59 and 60-69 years of age, with $p$ values of 0.028 and 0.031 , respectively. A strong association of mortality was also observed for patients with low creatinemia where the $p=0.038$.

\section{Conclusion}

In this study, $45 \%$ of patients undergoing hemodialysis at the Dialysis Center in Elbasan 
presented a BMI at normal values, $34.8 \%$ of them were pre-obese and obese and only $8.8 \%$ were underweight. The factors that lead to this growth are numerous. In our study some of the factors that resulted in strong significant correlations were gender, age, place of residence, educational level, smoking and Alcohol. There was no significant association between BMI and concomitant diseases of dialysis patients. Regarding mortality, a strong significant association was observed with age $50-69$ years and with post-dialysis cretinemia index. In paradoxical epidemiology, overweight becomes chronic on hemodialysis, as protective factors are associated with better survival. In our study, with a small number of chronic patients on hemodialysis, there was no significant association with some of the variables analyzed. There is a need to better understand the reverse epidemiological causes in individuals on dialysis, which can help us, improve the poor outcome in this population.

\section{Recommendations}

Obesity is recognized by its association with increased risk of CVD and mortality. However, in the paradoxical epidemiology, obesity becomes in chronic hemodialysis, a protective factor and is associated with better survival. Our study has a small population and cannot reach such a conclusion; further, studies with larger numbers are needed to support this concept with more center in dialysis. Hence, better examination of the reverse epidemiology is needed and may lead to improved survival. Therefore, further studies are needed to clarify the prognostic effect of abdominal obesity in dialysis patients in Albanian. We need nephrologist, nutritionist team work for: Getting the most benefit for the patient and more research for better evidence.

\section{References}

1. Park JM, Lee JH, Jang HM, Park Y, Kim YS, Kang SW, et al. Survival in patients on hemodialysis: Effect of gender according to body mass index and creatinine. PLoS One. 2018;13(5):e0196550. https://doi.org/10.1371/journal. pone.0196550

PMid:29768438

2. Beberashvili I,AzarA,Abu HamadR, Sinuani I, Feldman L, MaliarA, et al. Abdominal obesity in normal weight versus over weight and obese hemodialysis patients: Associations with nutrition, inflammation, muscle strength, and quality of life. Nutrition. 2018;59:7-13. https://doi.org/10.1016/j.nut.2018.08.002 PMid:30415161

3. Gorsane I, Mahfoudhi M, El Euch M, Younsi F, Abdallah TB. Obesity in hemodialysis patients. Int J Clin Med. 2015;6:667-71. http://dx.doi.org/10.4236/ijcm.2015.69089
4. Calle EE, Thun MJ, Petrelli JM, Rodriguez C, Heath CW Jr. Body-mass index and mortality in a prospective cohort of U.S. adults. N Engl J Med. 1999;341(15):1097-105. https://doi. org/10.1056/NEJM199910073411501

PMid:10511607

5. Vashistha T, Mehrotra R, Park J, Streja E, Dukkipati R, Nissenson AR, et al. Effect of age and dialysis vintage on obesity paradox in longterm hemodialysis patients. Am J Kidney Dis 2014;63(4):612-22. https://doi.org/10.1053/j.ajkd.2013.07.021 PMid:24120224

6. Stevens J, Cai J, Pamuk ER, Williamson DF, Thun MJ, Wood JL. The effect of age on the association between body-mass index and mortality. N Engl J Med. 1998;338(1):1-7. https://doi. org/10.1056/NEJM199801013380101

PMid:9414324

7. Grabowski DC, Ellis JE. High body mass index does not predict mortality in older people: Analysis of the longitudinal study of aging. J Am Geriatr Soc. 2001;49(7):968-79. https://doi. org/10.1046/j.1532-5415.2001.49189.x

PMid:11527490.

8. Oreopoulos A, Kalantar-Zadeh K, Sharma AM, Fonarow GC The obesity paradox in the elderly: Potential echanisms and clinical implications. Clin Geriatr Med. 2009;25(4):643-59. viii. https://doi.org/10.1016/j.cger.2009.07.005 PMid:19944265.

9. Oreopoulos A, Padwal R, Kalantar-Zadeh K, Fonarow GC, Norris CM, McAlister FA. Body mass index and mortality in heart failure: A meta-analysis. Am Heart J. 2008;156(1):13-22. https:// doi.org/10.1016/j.ahj.2008.02.014 PMid:18585492.

10. Oreopoulos A, Ezekowitz JA, McAlister FA, Kalantar-Zadeh K, Fonarow GC, Norris CM, et al. Association between direct measures of body composition and rognostic factors in chronic heart failure. Mayo Clin Proc. 2010;85(7):609-17. https://doi. org/10.4065/mcp.2010.0103 PMid:20592169

11. Freitas AT, Vaz IM, Ferraz SF, Mdo RP, Campos MI, Fornés NS. Prevalence and associated factors with abdominal obesity in hemodialysis patients in Goiânia. J Bras Nefrol. 2013;35:265-72. http://dx.doi.org/10.5935/0101-2800.20130045

12. Yang SY, Chiang CK, Hsu SP, Peng YS, Pai MF, Ho TI, et al. Metabolic syndrome predicts hospitalization in hemodialysis patients: A prospective Asian cohort study. Blood Purif 2007;25(3):252-9. http://dx.doi.org/10.1159/000101698 PMid:17429199

13. National Kidney Foundation. K/DOQI clinical practice guidelines for nutrition in chronic renal failure. Am J Kidney Dis. 2000;35(6 Suppl 2):S1-140. http://dx.doi.org/10.1053/ ajkd.2000.v35.aajkd03517

PMid:10895784

14. Kalantar-Zadeh K, Kopple JD, Kilpatrick RD, McAllister CJ, Shinaberger CS, Gjertson DW, et al. Association of morbid obesity and weight change over time with cardiovascular survival in hemodialysis population. Am J Kidney Dis. 2005;46(3):489-500. https://doi.org/10.1053/j.ajkd.2005.05.020 PMid:16129211

15. Kalantar-Zadeh K, Kuwae N, Wu DY, Shantouf RS, Fouque D, Anker SD, et al. Associations of body fat and its changes over time with quality of life and prospective mortality in hemodialysis patients. Am J Clin Nutr. 2006;83(2):202-10. https://doi. org/10.1093/ajcn/83.2.202 PMid:16469976

16. Kalantar-Zadeh K, Streja E, Molnar MZ, Lukowsky LR, Krishnan M, Kovesdy CP, et al. Mortality prediction by surrogates of body composition: An examination of the obesity paradox in 
hemodialysis patients using composite ranking score analysis. Am J Epidemiol. 2012;175(8):793-803.

PMid:22427612

17. Johansen KL, Young B, Kaysen GA, Chertow GM. Association of body size with outcomes among patients beginning dialysis. Am J Clin Nutr. 2004;80(2):324-32. https://doi.org/10.1093/ ajcn/80.2.324

PMid: 15277152

18. Ricks J, Molnar MZ, Kovesdy CP, Kopple JD, Norris KC, Mehrotra R, et al. Racial and ethnic differences in the association of body mass index and survival in maintenance hemodialysis patients. Am J Kidney Dis. 2011;58(4):574-82. https://doi. org/10.1053/j.ajkd.2011.03.023

PMid:21658829

19. Lievense $\mathrm{H}$, Kalantar-Zadeh K, Lukowsky LR, Molnar MZ, Duong $\mathrm{U}$, Nissenson $\mathrm{A}$, et al. Relationship of body size and initial dialysis modality on subsequent transplantation, mortality and weight gain of ESRD patients. Nephrol Dial Transplant. 2012;27(9):3631-8. https://doi.org/10.1093/ndt/ gfs131

\section{PMid:22553372}

20. Panzetta G, Abaterusso C. Obesity in dialysis and reverse epidemiology: True or false? G Ital Nefrol 2010;27(6):629-38. PMid:21132645

21. Flegal KM, Carroll MD, Ogden CL, Johnson CL. Prevalence and trends in obesity among US adults, 1999-2000. JAMA. 2002;288(14):1723-7. https://doi.org/10.1001/jama.288.14.1723 PMid: 12365955

22. World Health Organization. Obesity and Overweight Fact Sheet. Geneva: World Health Organization; 2017. Available from: http://www.who.int/news-room/fact-sheets/detail/obesity-andoverweight [Last accessed on 2021 Aug 12].

23. Asiki G, Mohamed SF, Wambui D, Wainana C, Muthuri S, Ramsay M. Sociodemographic and behavioural factors associated with body mass index among men and women in Nairobi slums: AWI-Gen project. Glob Health Action. 2018;11(2):1470738. https://doi.org/10.1080/16549716.2018.1 470738

PMid:29966508

24. Kramer HJ, Saranathan A, Luke A, Durazo-Arvizu RA, Guichan C, Hou S, et al. Increasing Body Mass Index and obesity in the incident ESRD population. J Am Soc Nephrol. 2006;17(5):1453-9. https://doi.org/10.1681/ASN.2005111241 PMid: 16597682

25. Xue JL, Ma JZ, Louis TA, Collins AJ. Forecast of the number of patients with end-stage renal disease in the United States to the year 2010. J Am Soc Nephrol 2016;12(12):2753-8. https://doi. org/10.1681/ASN.V12122753 PMid: 11729245

26. Peer N, Kengne AP, Motala AA, Mbanya JC. Diabetes in the Africa Region: 2013 Update for the IDF Diabetes Atlas; 2013.

27. Twagirumukiza M, De Bacquer D, Kips JG, de Backer G, Vander Stichele R, Van Bortel LM. Current and projected prevalence of arterial hypertension in sub-Saharan Africa by sex, age and habitat: An estimate from population studies. J Hypertens. 2011;29(7):1243-52. https://doi.org/10.1097/ HJH.0b013e328346995d PMid:21540748

28. Jha V, Garcia-Garcia G, Iseki K, Li Z, Naicker S, Plattner B, et al. Chronic kidney disease: Global dimension and perspectives. Lancet. 2013;382(9888):260-72. https://doi.org/10.1016/ S0140-6736(13)60687-X

PMid:23727169

29. Lozano R, Naghavi M, Foreman K, Lim S, Shibuya K, Aboyans V, et al. Global and regional mortality from 235 causes of death for 20 age groups in 1990 and 2010: A systematic analysis for the global burden of disease study 2010. Lancet. 2013;380(9859):2095-128. https://doi.org/10.1016/ S0140-6736(12)61728-0

PMid:23245604

30. Basu R, Man CD, Campioni M, Basu A, Klee G, Toffolo G, et al. Effects of age and sex on postprandial glucose metabolism: Differences in glucose turnover, insulin secretion, insulin action, and hepatic insulin extraction. Diabetes. 2006;55(7):2001-14 https://doi.org/10.2337/db05-1692

PMid:16804069

31. Veloso HJ, Silva AA. Prevalence and factors associated with abdominal obesity and overweight in adults from Maranhão. Rev Bras Epidemiol 2010;13:400-12.

32. Linhares RS, Horta BL, Gigante DP, Dias-da-Costa JS, Olinto MT. Distribution of general and abdominal obesity in adults in a city in southern Brazil. Cad Saúde Pública. 2012;28:438-48.

33. Postorino M, Marino C, Tripepi G, Zoccali C; CREDIT (Calabria Registry of Dialysis and Transplantation) Working Group. Abdominal obesity and all-cause and cardiovascular mortality in end-stage renal disease. J Am Coll Cardiol 2009;53(15):1265-72. https://doi.org/10.1016/j. jacc.2008.12.040 PMid:19358939

34. Elsayed EF, Sarnak MJ, Tighiouart H, Griffith JL, Kurth T, Salem DN, et al. Waist-to-hip ratio, body mass index, and subsequent kidney disease and death. Am J Kidney Dis. 2008;52(1):29-38. https://doi.org/10.1053/j.ajkd.2008.02.363 PMid: 18511168

35. Laurinavicius AG, Santos RD. Dyslipidemia, statins and chronic renal failure. Rev Bras Hipertens 2008;15:156-61.

36. Ohkawa S, Odamaki M, Ikegaya N, Hibi I, Miyaji K, Kumagai $\mathrm{H}$. Association of age with muscle mass, fat mass and fat distribution in non-diabetic haemodialysis patients. Nephrol Dial Transplant. 2005;20(5):945-51. https://doi.org/10.1093/ ndt/gfh643

PMid: 15769826

37. World Health Organization. Diet, Nutrition and Prevention of Chronic Diseases. Report of a Joint WHO/FAO Expert Consultation. Geneva: World Health Organization; 2003.

38. Matsudo SM, Matsudo VK, Neto TL. Impact of aging on anthropometric, neuromotor and metabolic variables of physical fitness. Rev Bras Ciên (RBCM). Rev Bras Ciên. 2000;8:21-32.

39. Ekart R; Hojs R. Obese and diabetic patients with end-stage renal disease: Peritoneal dialysis or hemodialysis? Eur J Intern Med. 2016;32:1-6. https://doi.org/10.1016/j.ejim.2016.03.016 PMid:27067614

40. Zaman SB, Hossain N, Rahman M. Associations between Body Mass Index and chronic kidney disease in Type 2 diabetes mellitus patients: Findings from the Northeast of Thailand. Diabetes Metab J. 2018;42(4):330-7. https://doi.org/10.4093/ dmj.2017.0052

PMid:30136452

41. Bae JP, Lage MJ, Mo D, Nelson DR, Hoogwerf BJ. Obesity and glycemic control in patients with diabetes mellitus: Analysis of physician electronic health records in the US from 2009-2011. J Diabetes Complications. 2016;30(2):212-20. https://doi. org/10.1016/j.jdiacomp.2015.11.016

PMid:26689451

42. Kalantar-Zadeh K, Block G, Humphreys MH, Kopple JD. Reverse epidemiology of cardiovascular risk factors in maintenance dialysis patients. Kidney Int 2003;63(3):793-808. https://doi.org/10.1046/j.1523-1755.2003.00803.x

PMid:12631061

43. Kopple JD, Zhu X, Lew NL, Lowrie EG. Body weight-for-height 
relationships predict mortality in maintenance hemodialysis patients. Kidney Int. 1999;56(3):1136-48. https://doi. org/10.1046/j.1523-1755.1999.00615.x

PMid:10469384

44. Lowrie EG, Lew NL. Death risk in hemodialysis patients: The predictive value of commonly measured variables and an evaluation of death rate differences between facilities. Am J Kidney Dis. 1990;15(5):458-82. https://doi.org/10.1016/ s0272-6386(12)70364-5

PMid:2333868

45. Coresh J, Longenecker JC, Miller ER $3^{\text {rd }}$, Young HJ, Klag MJ. Epidemiology of cardiovascular risk factors in chronic renal disease. J Am Soc Nephrol. 1998;9(1):S24-30.

PMid:11443765

46. Kalantar-Zadeh K, Kopple JD. Relative contributions of nutrition and inflammation to clinical outcome in dialysis patients. Am J Kidney Dis. 2001;38(6):1343-50. https://doi.org/10.1053/ ajkd.2001.29250

PMid:11728973
47. Fleischmann EH, Bower JD, Salahudeen AK. Risk factor paradox in hemodialysis: Better nutrition as a partial explanation. ASAIO J. 2001;47(1):74-81. https://doi. org/10.1097/00002480-200101000-00016

PMid:11199320

48. Nishizawa $Y$, Shoji T, Ishimura E, Inaba M, Morii H. Paradox of risk factors for cardiovascular mortality in uremia: Is a higher cholesterol level better for atherosclerosis in uremia? Am J Kidney Dis. 2001;38(1):S4-7. https://doi.org/10.1053/ajkd.2001.27380 PMid:11576913

49. Ritz E, Nowicki M, Wiecek A. Excess cardiovascular mortality in the uremic patient What does it teach for other risk factors in the non-renal patient? Pol Arch Med Wewn. 1994;92(Spec No):110-6.

PMid:7731891

50. Mohammedi K, Chalmers J, Herrington W, Li Q, Mancia G, Marre $\mathrm{M}$, et al. Associations between body mass index and the risk of renal events in patients with Type 2 diabetes. Nutr Diabetes 2018;8(7):7. https://doi.org/10.1038/s41387-017-0012-y

PMid:29343817 